\title{
Kajian Studi Kasus Social Enterprise dari Sudut Pandang Konsep Design for Happiness
}

\author{
Devanny Gumulya \\ Desain Produk, Fakultas Desain, Universitas Pelita Harapan \\ e-mail: devanny.gumulya@uph.edu
}

\begin{abstract}
Abstrak - Perkembangan teknologi manufaktur dan informasi mendorong perubahan nilai-nilai perekonomian. Berdasarkah hasil riset dari Philips di tahun 2014, dinyatakan akan makin besar ekonomi berbasis transformasi. Dalam konteks ini muncullah, bisnis bermodel social enterprise, bisnis yang bertujuan untuk menangani masalah sosial, meningkatkan kapasitas komunitas, memberikan pekerjaan dan training kepada komunitas, atau membantu lingkungan. Dalam kurun waktu lima tahun terakhir start up berbasis social enterprise mengalami peningkatan yang cukup signifikan baik secara local maupun global. Di sisi lain, Design for happiness adalah desain yang memberikan kebahagiaan pada konsumen, melalui tiga hal desain yang memelihara hubungan sosial, desain yang memaknai kehidupan seseorang, desain yang membuat konsumen berpartisipasi aktif. Dalam tulisan ini, dikaji tiga bisnis social enterprise : Sukhacitta, Du'Anyam dan Toms, bagaimana ketiga bisnis ini menjalankan visinya dan dianalisa dari kacamata design for happiness: bagaimana visi diimplentasikan dalam konteks desain yang secara eksplisit bisa dilihat kostumer. Hasil kajian adalah masing-masing social enterprise memiliki keunikannya masing-masing, tapi ada tiga elemen yang paling dapat mencerminkan visi social enterprise. Yang pertama adalah produk dengan desain yang gaya casual dan nyaman untuk kegiatan sehari-hari, yang kedua adalah logo yang mengkomunikasikan visi tidak literal tapi konsumen dapat menghubungkan visi dan logo dengan mudah bila membaca informasi yang ada di website. Yang ketiga adalah konten sosial media bercerita pembangunan kapasitas dan peningkatan kualitas hidup komunitas yang dibangun.
\end{abstract}

Kata kunci: bisnis sosial, desain untuk kebahagiaan, desain produk

Abstract - The rapid development of technology and information system changes the people's perception of what constitutes as economical value. There are four economic paradigms: the industrial, experience, knowledge and transformation economies. It is also stated that transformative economy will be bigger in the coming year. Within this context come the concept of social enterprise. Business with a vision to solve social problem and to build impoverished communities's capacities, give job and training to the community or helping solving environmental problem. Within last five years, social enterprises show growth significantly locally and globally. On the other hand, design for happiness is a concept in which design could give happiness to its consumer through three approaches: design for fostering social relationships and belongingness, design for meaning in life, design for happiness makes consumers active. In this paper analyzed three social enterprises: Sukhacitta, Du'Anyam and Toms. How they run their mission under design for happiness perspective. The study shows that each social enterprise has its own uniqueness. There are three elements that could describe their vision the best. The first one is trough making products that are casual and comfortable for daily use, second their logo should communicate the vision not literal but people could connect easily by reading the information in the website. The last one is social media content should describe the social activities that have been done to improve the quality of communites's life.

Keywords: social enterprise, design for happiness, product design

\section{PENDAHULUAN}

Sepanjang sejarah kehidupan manusia, persepsi manusia akan nilai dipengaruhi oleh perubahan sosial budaya [1]. Berdasarkan hasil penelitian mengenai perkembangan ekonomi dunia oleh Philips yang berjudul, "Rethinking Values In Changing Landscape" di tahun 2011, disebutkan ada empat paradigma ekonomi yang sudah terjadi, masih berlangsung dan prediksinya kedepan.

\section{a. Ekonomi berbasis industrialisasi}

Kemajuan ekonomi sebagai hasil dari revolusi industri di abad 18-19. Pada paradigma ini nilai yang dipegang adalah efisiensi produksi. Revolusi industri merevolusi peradaban manusia, kemajuan perkembangan transportasi dan teknologi komunikasi merubah pemikiran manusia. Dari sudut pandang ilmu filsafat, industrialisasi adalah buah dari modernisme, pola pikir yang berorientasi pada progress dan selalu berpikir kedepan. Nilai yang dipegang dalam paradigma ini adalah efisiensi, rasional, fungsionalitas. Produk dibuat secara massal untuk menekan harga produksi, sehingga dapat dikonsumsi banyak orang, tapi kekurangannya adalah produk menjadi tidak ada keunikan satu sama lain. Paradigma ekonomi ini sudah berjalan dua abad lebih, dan bahkan masih dilakukan sampai saat ini di Negara berkembang seperti Indonesia.

\section{b. Ekonomi berbasis pengalaman}

Pada tahun 1950an di negara - negara barat, pola pikir modernis mulai ditinggalkan. Nilai-nilai yang dipegang sebelumnya: rational, universalisme dan kemajuan teknologi dan sains berujung pada konsumerisme. Pada tahun 1960an, muncul keinginan untuk mencari paradigma yang baru yang menegasi nilai - nilai modernisme. Ekonomi berbasis pengalaman muncul sebagai jawaban, untuk mengisi kekosongan hasil dari pemikiran modernis yang bersifat universal dan rationalis. Hasil dari industrilisasi adalah produk semakin banyak dipasar dan bersaing harga. Maka perusahaan harus mencari keunikannya dimata pasar. Setelah paradigma sebelumnya sangat berorientasi pada hal - hal fisik, maka paradigma ini mengalihkan fokusnya pada hal - hal non fisik seperti pengalaman, merek, branding yang menjadi pusat dari paradigma ini. Kunci kesuksesan dari branding adalah segmentasi pasar. Bagi konsumen produk bermerek menjadi sarana berekspresi gaya hidup dan untuk mengasosiasikan 
dirinya dengan kelas ekonomi tertentu dan subkulturnya. Konsumen, membeli produk dan servis yang menurut mereka dapat menambah nilai pribadi mereka, dengan memecahkan masalah kehidupan sehari-hari mereka, atau membantu mereka meraih tujuan tertentu yang mereka anggap penting. Perusahaan tidak lagi menjual produk tapi pengalaman yang didapatkan ketika menggunakan produk tersebut. Aspirasi, identitas, narasi menjadi penting dalam paradigma ini.

\section{c. Ekonomi berbasis pengetahuan}

Paradigma ekonomi berbasis pengalaman muncul karena strategi branding sudah sulit dilakukan. Setiap tahun keluar brand baru menawarkan pengalaman yang hampir mirip dengan harga yang lebih murah. Hal ini mendorong paradigma berbasis pengetahuan. Kemajuan telekomunikasi, internet, web 2.0 di tahun 1999 mendorong munculnya banyak komunitas online. Pada era ini orang dengan mudahnya bertukar informasi, transfer pengetahuan dan keahlian dalam komunitasnya. Di paradigma ini semangat untuk berkolaborasi, tukar menukar dari hal yang bersifat non fisik seperti informasi hingga hal yang bersifat fisik seperti produk, pemberdayaan diri, keterbukaan menjadi sangat penting Customer tidak lagi menerima informasi, tapi sekarang menjadi pembuat konten informasi yang ia rasa berguna bagi komunitasnya. Contoh dari paradigma ini adalah Wikipedia, ensiklopedia informasi berbasis web yang dapat ditulis dan dibaca setiap orang dengan mudah dan tanpa menyebutkan nama penulis.. Setiap orang menjadi haus akan informasi digital dan ingin mengaktualisasi dirinya. Buah dari paradigma ini adalah bisnis baru yang dikenal dengan start up bertumbuh subur, karena kemudahan akses ke pasar dan supply chain semakin pendek. Start up yang menawarkan solusi berbasis network seperti Uber, Grab, Gojek bertumbuh dengan pesat.

\section{d. Ekonomi berbasis transformasi}

Paradigma ini diperkirakan akan semakin besar di beberapa tahun kedepan. Paradigma ini muncul karena ketiga paradigma sebelumnya, semuanya mengakibatkan polusi, pemanasan global, kemiskinan, kesenjangan ekonomi, kondisi bekerja di negara produsen yang tidak baik demi efisiensi. Konsep berkelanjutan, kesamaan visi customer dan perusahaan, empati dan etika menjadi nilai - nilai penting dalam paradigma ini, karena customer semakin kritis akan produk yang dikonsumsinya apakah dibuat secara ramah lingkungan dan etis. Setelah mendapatkan banyak informasi di paradigma sebelumnya, di era ini customer ingin melakukan sesuatu yang baik dan bersifat transformatif bagaimana membantu isu-isu global seperti kemiskinan, pemanasan global dengan ilmu dan keahlian yang dimilikinya. Kolaborasi dengan pemerintah, swasta, masyarakat juga diperlukan untuk memecahkan masalah pencemaran lingkungan dan kemiskinan. Paradigma ini juga sangat mendorong konsumsi produk local dan mengkonsumsi produk yang memang lagi musimnya, sehingga tidak menghabiskan banyak emisi karbon untuk pemenuhan kebutuhan produk tersebut. Solusi transformatif yang diharapkan adalah yang bersifat sistemik, jadi transformasi terjadi diseluruh rantai bisnis dari input hingga output, lingkungan dan manusia mengalami perubahan yang bersifat positif.

Dari latar belakang paradigma ekonomi berbasis transformatif, maka mulai muncul pemikiran yang bersifat utopis, bahwa ekonomi yang baik mentransformasi manusia dan lingkungannya ke arah yang lebih baik [2 dan 3].

Di era paradigma ekonomi berbasis transformatif yang mulai terjadi khususnya di negara barat sejak sepuluh tahun terakhir melahirkan banyak bisnis baru yang memiliki visi transformatif yang disebut sebagai social enterprise. Departemen Bisnis dan Inovasi Inggris mendefinisikan social entreprise sebagai bisnis yang memiliki tujuan social dimana kelebihan hasil usaha diinvestasikan kembali ke komunitas dimana bisnis tersebut berada, jadi tidak berorientasi untuk meningkatkan keuntungan para stakeholder. Social traders.au mendefinisikan social enterprise sebagai bisnis yang bertujuan untuk menangani masalah social, meningkatkan kapasitas komunitas, memberikan pekerjaan dan training kepada orang, atau membantu lingkungan.

Bisnis berkonsep social entreprise juga mulai masuk ke Indonesia. Hal ini yang menarik untuk dikaji, bagaimana bisnis yang memiliki visi transformatif menjalankan bisnisnya melalui kacamata konsep design for happiness. Konsep ini dibutuhkan karena latar belakang desain penulis, maka dibutuhkan penghubung antara pemikiran ekonomi dan sisi desainnya.

Tujuan yang mau dicapai dalam kajian ini adalah :

1. Mereview social enterprise yang sudah ada saat ini

2. Rekomendasi dalam konteks design for happiness bagi perkembangan social enterprise

\section{TINJUAN PUSTAKA}

Dalam konteks ekonomi berbasis transformasi muncul topik penelitian dalam desain tentang desain yang dapat mendatangkan kebahagiaan (design for happiness).

Design for happinessberarti desain yang bertujuan untuk memberikan kebahagiaan bagi konsumen. Produk yang dihasilkan oleh design for happiness bukan produk yang semata-mata hedonis dan bersifat membuat bahagia sementara, namun produk yang mendukung orang untuk bereaksi atau berfikir dengan cara yang dapat mendukung kebahagiaan jangka panjang mereka, atau mencegah penyebab ketidakbahagiaan. Konsep ini baru bisa direalisasikan bila semua stakeholder dalam perusahaan memiliki visi yang semua, terutama divisi desain dan pemasar, jadi antara produk dan strateginya mengkomunikasikan ke konsumen hal yang sama.

\section{Variabel Design for Happiness}

Design for happiness dibagi menjadi tiga poin yang dianggap penting dan saling mendukung.

\section{Desain yang memelihara hubungan sosial}

Relasi sosial yang kurang baik dapat manusia menjadi tidak bahagia. Karakter desain yang memelihara hubungan social harus dibentuk oleh desainer dan pemasar secara bersama sama, yaitu:

- Desain yang mendukung orang untuk melakukan hal untuk orang lain.

- Desain yang mengajak orang untuk melakukan hal bersama dengan orang lain dibandingkan dengan pemakaian pribadi. Disini akan terbentuk rasa kepemilikan bersama.

- $\quad$ Desain yang mengajak orang untuk berbagi. 
- Desain yang mengajak orang untuk berinteraksi dengan orang lain. Interaksi berarti berinteraksi dengan verbal dan fisik dengan orang lain (Contoh, duduk disamping orang lain, berada di ruangan yang sama).

- Pemasar harus memastikan bahwa mereka mengkomunikasikan keterlibatan bisnis perusahaan tersebut dengan kegiatan non-profit atau yang berhubungan dengan komunitas.

- $\quad$ Di kampanye pemasar dan komunikasi, pemasar harus menekankan interaksi diantara konsumen, meningkatkan kebersamaan, kesamaan, dan kepemilikan sebelum individualitas

\section{Desain yang memaknai kehidupan seseorang}

Pada kehidupan yang kontemporer, sering dirasakan rasa kehampaan makna. Desain untuk kebahagiaan harus berarah untuk mendukung atau menyediakan rasa dan makna kehidupan untuk konsumen.

Karakter desain yang memaknai kehidupan sesorang yang harus dibentuk oleh desainer dan pemasar secara bersama sama, yaitu:

- $\quad$ Desain yang mendukung tujuan berbeda yang dimiliki orang dalam hidup, seperti hubungan romantis, karir, dan sebagainya, memegang implikasi yang penting untuk desainer. Di konteks ini, sangat penting untuk mengerti adanya tujuan yang cukup bagi seorang individu, walaupun hasilnya tidak tercapai [4].

- Desain yang membuat konsumen merasa mereka memiliki kontrol, kemampuan untuk berdampak pada acara atau hidup seseorang.

Pemasar menekankan konsep bisnis sebagai suatu alat untuk mencapai tujuan yang penting bagi konsumen dan meningkatkan perasaan konsumen memiliki kontrol.

3. Desain yang membuat konsumen berpartisipasi aktif, bukan pengamat. Konsumen yang ingin bahagia harus berfokus pada membeli pengalaman, bukan produk yang materiil. Berfokus pada doing, bukan having, karena berdasarkan penelitian dari psikologi positif menunjukan bahwa orang yang senang menjaga dirinya sibuk dan aktif. Jadi aktivitas adalah bibit kesenangan.

Karakter desain yang membuat konsumen partisipan aktif, bukan pengamat harus dibentuk oleh desainer dan pemasar secara bersama-sama, yaitu:

a. Desain yang berfokus pada doing, bukan having.

b. Desain yang mendukung dan memupuk pengembangan diri/skill-skil baru.

c. Untuk produk berwujud, pemasar harus menekankan apa saja yang dapat dilakukan konsumen dengan produknya, bukan apa yang akan konsumen tersebut dapatkan.

d. Menekankan pengembangan-pengembangan diri di komunikasi pemasaran.

\section{METODE}

Dari tinjuan pustaka, maka dibuat matriks untuk mengkaji studi kasus social enterprise dari sudut pandang konsep design for happiness (Gambar 1). Tujuannya agar terlihat jelas karakter desain for happiness yang paling terlihat dari studi kasus bisnis social entreprise yang dikaji.

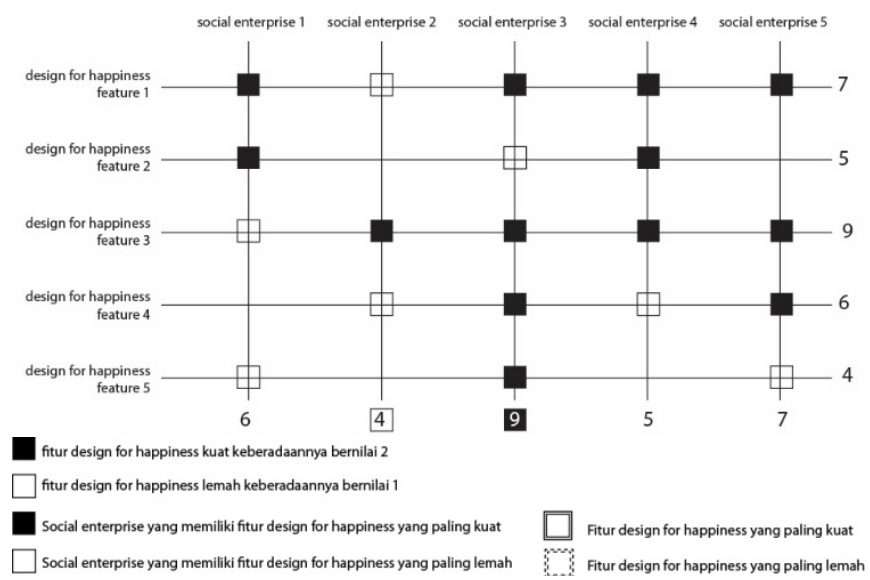

Gambar 1. Matriks untuk menguji studi kasus social enterprise dari sudut pandang design for happiness

\section{HASIL}

Dikumpulkan data bersumber dari daring online beberapa social entreprise yang ada dalam kurun waktu lima tahun terakhir.

\section{Sukhacitta}

SukkhaCitta adalah sebuah social enterprise yang bervisi untuk mensejahterakan para pengrajin perdesaan di Indonesia, agar mereka mendapat pendapatan yang lebih layak, mengangkat mereka dari kemiskinan sambil mempertahankan keahlian mereka melalui akses terhadap pengetahuan dan pasar [5 dan 6]. Denica Flesch (sebagai founder dari SukkhaCitta) percaya bahwa apa yang manusia lakukan selalu berdampak bagi sekitarnya. Nilai ini yang mempengaruhi ibu Denica untukmembangun SukkhaCitta ketika ia ingin tahu penyebab kegagalan dalam merubahkondisi dari komunitas peedesaan. Setelah ditelusuri, ia melihat kerajinan tangan menjadi penyongkong hidup mereka ditengah keterbatasan dan kemiskinan. Oleh karena itu, SukkaCitta ada sebagai sarana untuk mengatasi kesenjangan pasar dan mempertemukan mereka dengan para konsumen. Dengan tagline \#MadeRight, SukkhaCitta mempromosikan upah yang layak, praktik lingkungan yang berkelanjutan dan melestarikan budaya.

Nama Sukkhacita mempunyai arti yaitu kebahagiaan dalam bahasa Sanskrit, akar dari kata 'sukacita' dalam bahasa Indonesia. Itu adalah sebuah perwujudan dari misi yang ingin dicapai, yaitu untuk menceritakan dan membuat dampak dalam setiap kain yang dijual. Produk dari SukkhaCitta dikategorikan berdasarkan desa-desa yang berada dibawahnaungannya serta cerita yang menjadi latar belakangnya. SukkhaCitta mempromosikan bahwa setiap desa memiliki kerajinan dan material yang unik. Berikut adalah beberapa kategori dari produk SukkhaCitta beserta contoh produknya:

Pada Gambar 2 dan 3 dapat dilihat katagori produk sukkhacita. Sukkhacita menjual produk - produk yang sustainable melalui kejelasan dan keadilan, dimana produk - 
produk dapat dilacak dimana, bagaimana, dan mengapa sukkhacita memproduksinya.

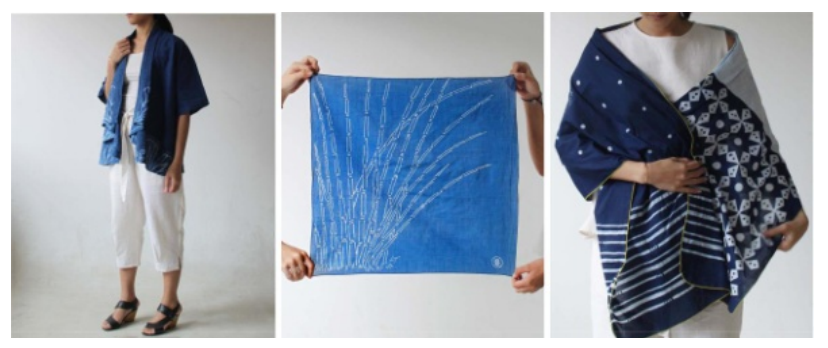

Gambar 2. JLAMPRANG: Batik Tulis Sumber: www.sukhacitta.com

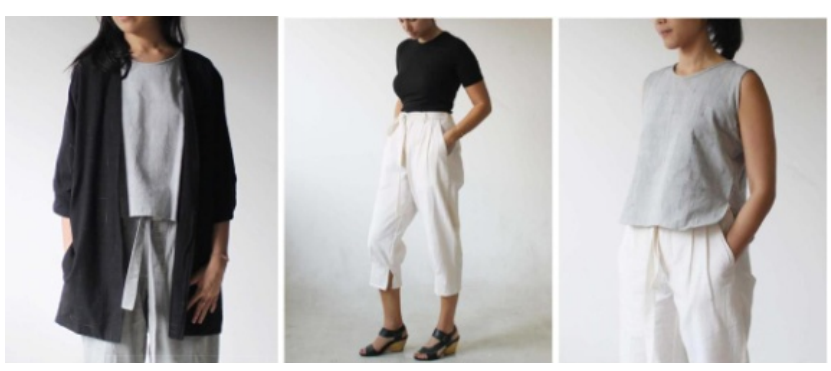

Gambar 3. MEDONO: Kain Tenun

Sumber: www.sukhacitta.com

Sukkhacita mengimplementasi One Village One Collection Model, yaitu satu desa satu koleksi model dalam Bahasa Indonesia. Mereka mempunyai 4 desa binaan yang membuat produk dengan cara produksi yang berbeda di Jawa Tengah. Di Desa Jlamprang, ada 2 inisiatif yang dilakukan sukkhacita; memberikan pelatihan bisnis dasar kepada keluarga sambil melatih 10 perempuan yang pengangguran atau yang bekerja di sawah untuk menjadi pengrajin Batik. Di Desa Medono, Sukkhacita memberi 8 penenun upah yang layak dan juga menjaga kelangsunan kerajinan tenun dengan meningkatkan status handloomed textiles di pasar modern. Sukkhacita juga ingin memulai untuk lebih melibatkan istri penenun dan meningkatkan upaya mereka melalui proyek daur ulang benang. Di Desa Gesikharjo, Sukkhacita mempunyai program pengembangan kapasitas pewarna alami. Mereka melakukan pelatihan dan menginvestasi alat dan bahan untuk mengurangi ketergantungan kepada pewarna sintetis. Dengan ini, pendapatan bulanan pengrajin dapat naik menjadi $60 \%$. Di Desa Gaji, Sukkhacita memulai koperasi tenun pertama disana. Sukkhacita mendukung pengrajin dengan upah hidup mereka sehari - hari dan juga mengajari wanita desa untuk kembali mempelajari kerajinan yang sudah hilang ini.

Sukhacitta menerapkan prinsip \#MadeRight, dimana mereka ingin pengrajin - pengrajin mereka untuk mempunyai pendapatan yang layak, mempromosikan sustainable design, dan mempertahankan budaya melewati setiap produk yang terjual. Sukkhacita ingin memberi setiap dari produk sebuah cerita yang spesial, yang mengingatkan kita untuk mengapresiasikan pengrajin yang sudah membuat produk mereka. Value - value Sukkhacita terpancar dari pemilihan bahan baku dan metode produksimereka. Sukkhacita selalu menggunakan kearifan setiap desa untuk membuat produk - produk mereka melalui One Village One Collection Model. Mau itu penjualan adonan indigo dari Desa Jlamprang, teknik Double Ikat dari Desa Medono, ataupun Batik Tulis dari Desa Gesikharjo.

\section{Du'Anyam}

Du'Anyam merupakan suatu perusahaan sosial yang menghasilkan produk kerajinan daun lontar. Perusahaan yang berdiri pada tahun 2014 ini memulai proyek pertamanya di Kota Larantuka, NTT, yang merupakan provinsi termiskin dengan tingkat kelahiran dan kematian yang tinggi. Komunitas yang menjadi sorotan Du'Anyam adalah komunitas para ibu diprovinsi Nusa Tenggara Timur [7]. Masalah yang timbul dari komunitas ini adalah kemiskinan serta angka kelahiran dan kematian ibu dan anak yang tinggi. Karena kemiskinan, para ibu harus bekerja dimana di daerahnya kebanyakan pekerjaan ladang, akibatnya angka kematian ibu dan anak menjadi tinggi. Selain itu, kemiskinan juga menyebabkan kurangnya gizi yang didaptkan oleh ibu dan anak. Du'Anyam memberikan lapangan kerja bagi wanita di NTT, khususnya bagi ibu pada usia subur atau hamil. Oleh karena itu, kata du'anyam itu sendiri diambil dari bahasa lokal yang berarti ibu menganyam

Du'Anyam bervisi untuk meningkatkan kesehatan dan mutu hidup wanita yang ada di NTT, khususnya bagi ibu hamil. Ibu yang memiliki penghasilan yang minim ini harus tetap pergi ke ladang meskipun sedang hamil. Dengan rendahnya pendapatan yang dimiliki, banyak ibu yang tidak mampu mengecek kesehatan dan memiliki gizi yang baik, dan mengakibatkan banyak terjadi keguguran. Akhirnya, Du'Anyam ingin membantu para ibu dan memberi kesempatan pada para ibu untuk meningkatkan mutu hidupnya. Selain itu, NTT juga memiliki suatu kerajinan yang menjadi karakter dari NTT itu sendiri, yaitu kain tenun dan menganyam. Pada akhirnya, Du'Anyam mengambil kerajinan anyaman karena anyaman NTT masih belum dikembangkan, bahkan di masyarakat itu sendiri. Dengan pertimbangan mengenai kecepatan pembuatan dan proses produksi, akhirnya Du'Anyam memulai pembuatan kerajinan tangan anyaman sedeharna sandal hotel, dengan bantuan sepuluh ibu. Kemudian sandal inidipasarkan ke hotel. Hingga saat ini, setelah berdiri lebih dari 3 tahun, Du'Anyam sudah berhasil membantu 40 pengrajin ibu dari 16 desa dan meningkatkan $40 \%$ daripenghasilan wanita, serta meningkatkan kesenjangan gender antara pria dan wanita.

Misi Du'Anyam memiliki 3 landasan/pilar, yaitu pemberdayaan ekonomi, peningkatan kesehatan, dan promosi budaya lokal. Pengembangan ekonomi dilakukan dengan meningkatkan produktivitas dan kualitas produk lokal, memfasilitasi akses ke pasar local dan global, dan mempererat organisasi penganyam. Keuntungan dari penjualan Du'Anyam akan disisihkan dalam bentuk tabungan kesehatan, digunakan untuk membiayai edukasi mengenai gaya hidup sehat, serta pembelian makanan bergizi bagi para ibu hamil.

Pada Gambar 4 dapat dilihat produk Du'Anyam terbagi menjadi dua kategori yaitu living dan style. Produk yang termasuk dalam kategori living merupakan produk seperti keranjang, home decor, indoor slippers, box penyimpanan, dan baki (tray). Sedangkan produkyang termasuk dalam kategori style merupakan aksesoris seperti tas, dompet, sandal hingga luggage tag.

Du'Anyam menjual produk yang diproduksinya secara wholesale dan retail. Sistem wholesale diberlakukan bagi hotel (mayoritas di Jakarta dan Bali) dan institusi lainnya, dengan menyediakan produk seperti sandal hotel, merchandise, gifts, dan sebagainya. Dengan memiliki 
sekitar 40 wholesale client selama ini, Du'Anyam memperoleh $80 \%$ dari pendapatannya dari hasil penjualan wholesale.

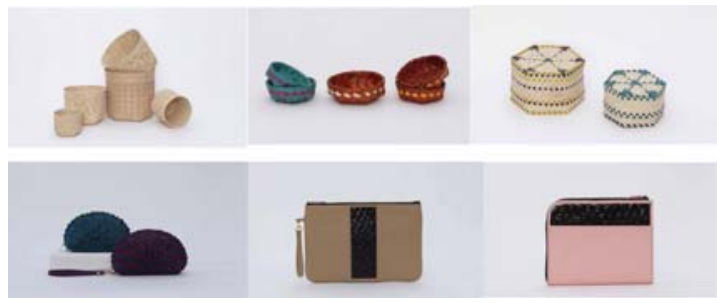

Gambar 4. Produk Du'Anyam

Sumber: https://www.duanyam.com

Pada akhir tahun 2016, Du'Anyam memulai penjualan secara retail kepada end-user, yaitu masyarakat muda berumur 20-30 tahun sebagai fokusnya. Du'Anyam memiliki tujuan agar anak muda dapat turut membantu meningkatkan budaya lokal, namun tetap fashionable dan trendy. Dilihat dari letak toko offline, sosial media, dan pertanyaan survey yang sedang dilakukan di sosial media, Du'Anyam sedang mengembangkan fashion wanita yang modern dan fashionable. Selain dijual secara lokal, Du'Anyam juga mulai masuk secara international, seperti di Jepang dan Australia. Selain itu, Du'Anyam juga melakukan kolaborasi dengan beberapa merek lokal untuk membantu dalam penjualan retail.

Pembeli dan publik melihat Du'Anyam sebagai suatu usaha sosial yang sangat baik karena dapat mengangkat aspek kehidupan pula. Dilihat dari berbagai video di berbagai program tv dan pada foto di Instagram Du'Anyam, dapat dilihat bahwa misi sosial ini membawa dampak dan respon yang baik, bukan hanya secara lokal, namun juga di dunia internasional. Menurut publik, Du'Anyam merupakan suatu usaha yang kreatif dimana masalah yang ada di Indonesia diangkat dan dijadikan suatu peluang perusahaan untuk memperbaiki masalah tersebut

Du'Anyam ingin meningkatkan kualitas hidup para pengrajinnya dalam hal kesehatan dan perekonomiannya. Untuk itu Du'Anyam melakukan beberapa hal. Pertama, mereka mulai bersosialisasi kepada komunitas untuk mendapatkan kepercayaan mereka, kemudian Du'Anyam mengalihkan pekerjaan ladang para ibu, dari pekerjaan berat di ladang menjadi penganyam daun lontar yang dapat dilakukan oleh sebagian besar para ibu. Kedua, mereka membeli daun lontar dari komunitas lokal. Kemudian produk yang dihasilkan oleh pengrajin akan dinilai berdasarkan kualitasnya dan para pengrajin akan dibayar sesuai dengan kualitas produk yang mereka hasilkan. Hal ini dilakukan untuk memberdayakan para pengrajin dimana mereka tetap harus bekerja untuk mendapatkan penghasilan.Setelah itu, Du'Anyam juga mulai membuat pelatihan dan fasilitas untuk para pengrajin yang dapat mendukung pekerjaan menganyam mereka. Contoh pelatihan yang dibuat oleh Du'Anyam adalah pelatihan bagaimana para pengrajin dapat menghasilkan produk dengan kualitas yang mirip sehingga kualitas yang ditawarkan kepada konsumen tetap konsisten.

\section{Toms}

Sebuah perusahaan yang mendesain dan menjual sepatu, kacamata, kopi, dan tas. Perusahaan ini didirikan pada tahun
2006 oleh Blake Mycoskie yang berasal dari Texas [8]. Ketika beliau mengunjungi Argentina, Blake menyadari bahwa banyak anak-anak di sana yang tumbuh tanpa memiliki sepasang sepatu. Beliau ingin membantu dengan mendirikan for-profit business yang berkelanjutan dan tidak bergantung pada donasi. Demikianlah awal mula Toms shoes, yang akan membantu satu orang setiap kali sebuah sepatu dibeli. Desain sepatu toms juga mengambil dari sepatu klasik dari Argentina yang disebut dengan sepatu apalgartas. Apalgartas sendiri adalah nama dari penghasil kain tekstil terbaik di Argentina. Karena kualitas kainnya sangat baik maka dibuat sepatu. Sepatu Apalgartas adalah sepatu tradisional yang dipakai oleh Gaucho (koboi di Amerika Selatan). Sepatu ini sering dipakai untuk berkuda, berternak oleh pria maupun wanita.
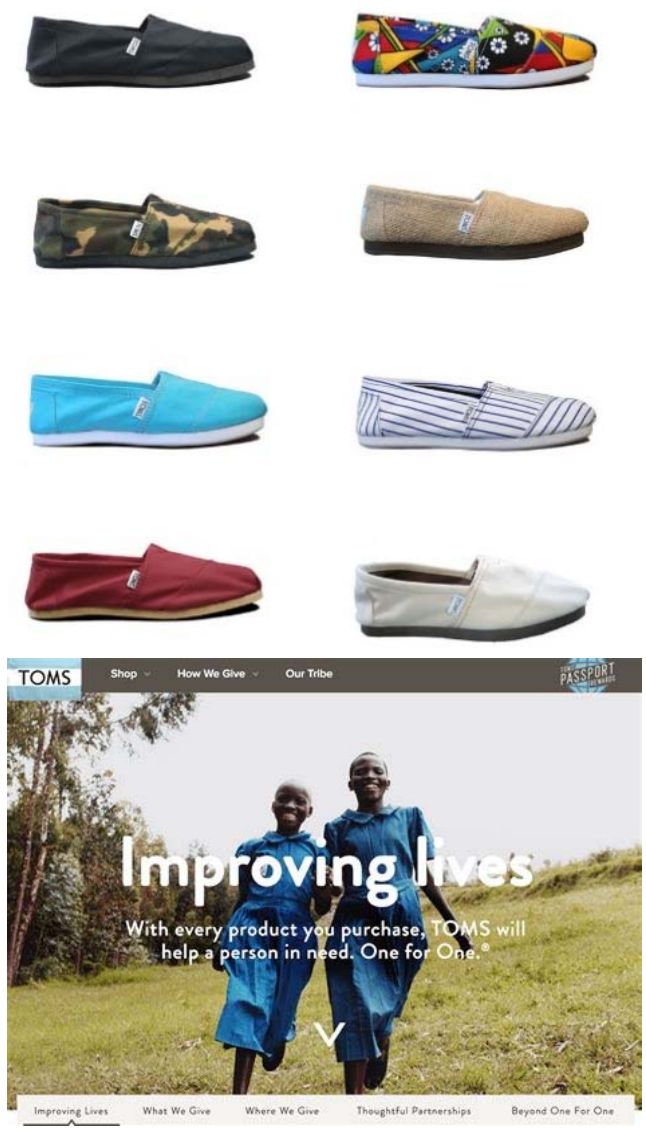

Gambar 5 Produk dan Website TOMS

Sumber: https://www.toms.com

Kategori produk Toms Shoes dibagi dalam wanita, pria dan anak-anak. Pada wanita dan pria terdapat kategori sepatu, kacamata hitam, tas dan baju. Gambar 5 merupakan contoh dari produk Toms.

Misi sosial Toms adalah "One for One", yang menggambarkan janji perusahaan tersebut untuk membantu seseorang yang kesulitan setiap ada sebuah produk yang dibeli. Toms menyadari bahwa value "One for One" dapat diaplikasikan ke aspek kebutuhan hidup lainnya di samping sepatu. Dari awalnya hanya menjual dan memberikan sepatu setiap ada sepasang yang terjual, Toms berkembang dan mengeluarkan koleksi kacamata di tahun 2011, di mana setiap pasang kacamata terjual akan membantu memperbaiki kesehatan mata seorang yang membutuhkan. Selanjutnya, Toms memproduksi kopi (TOMS Roasting Co. 
pada 2014) di mana setiap kopi terjual akan membantu satu orang mendapatkan air bersih selama satu minggu. Terakhir, Toms memproduksi juga koleksi tas (TOMS Bag Collectionpada 2015) di mana setiap satu tas terjual akan membantu proses persalinan satu wanita yang membutuhkan.

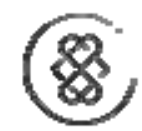

S UKKHA CIT TA
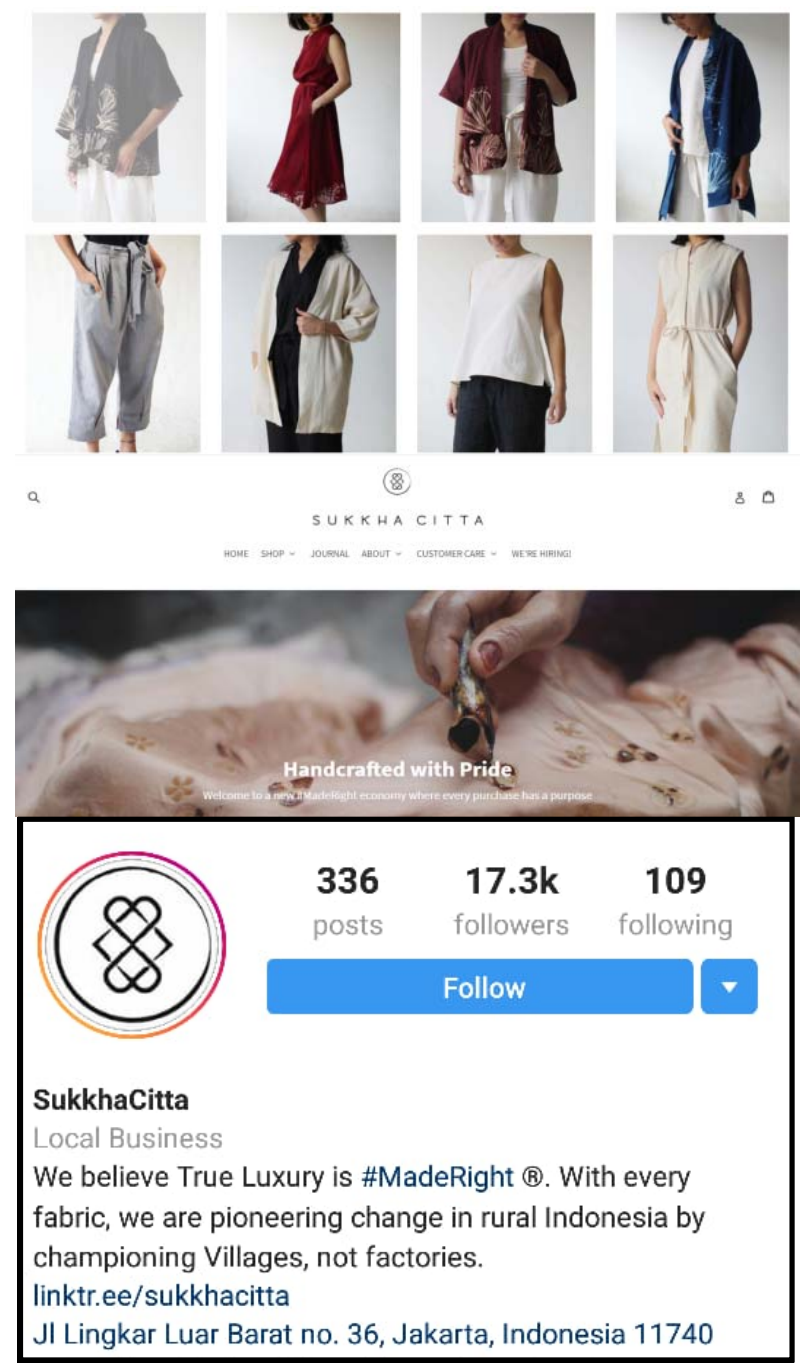

Gambar 6 Produk, Website dan Akun social media Sukhacitta (a)

Sumber: https://www.sukhacitta.com dan Instagram Sukhacitta

Pada tahun 2013, TOMS berkomitmen untuk memproduksi sepertiga dari sepatu pemberian mereka di wilayah yang diberi bantuan oleh TOMS sebelumnya. Produksi lokal membantu membangun industri dan menciptakan lapangan kerja dan masa depan. Karena mereka berkomitmen pada produksi lokal, TOMS telah menciptakan lebih dari 700 pekerjaan di wilayah yang mereka berikan, sepatu buatan lokal di Ethiopia, India dan Kenya. Petani dibayar dengan adil berarti para petani dijamin dibayar dengan harga terbaik. Setiap pembelian TOMS Roasting Co, keuntungannya digunakan TOMS untuk mendukung petani dan masyarakat yang membutuhkan akses air bersih yang lebih baik.

Pembeli produk Toms Shoes terdiri dari kalangan yang berbeda-beda mulai dari anak-anak, remaja, dewasa hingga orang tua karena produk Toms Shoes terutama sepatu memang dirancang sesuai dengan umur customernya. Sepatu Toms Shoes telah didistribusikan ke berbagai negara di belahan dunia. Pada tahun 2016 Toms menyumbangkan 27.435 sepatu untuk anak-anak di seluruh dunia.

Selanjutnya dikaji bagaimana nilai-nilai design for happiness yang adalah ranah makna diwujudkan dalam bahasa desain yang dapat dilihat langsung oleh konsumen berupa: bentuk, warna, material, style produk, logo, serta konten social media.

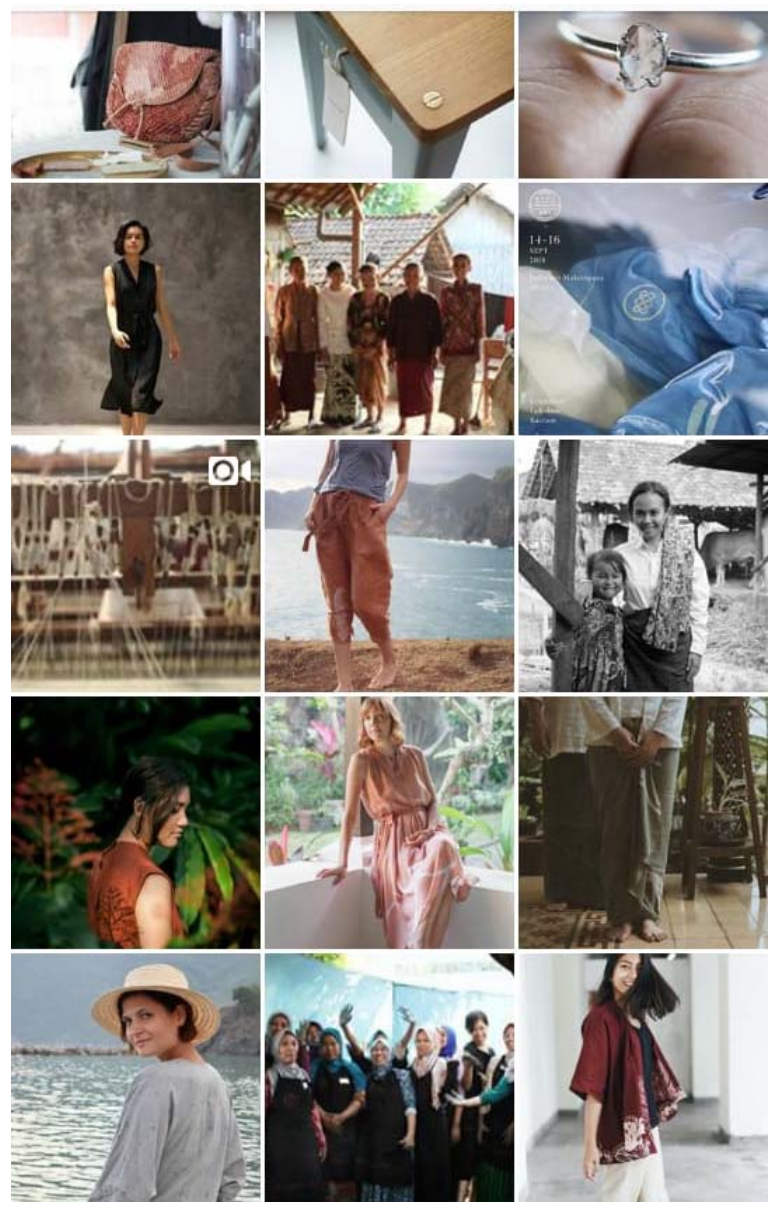

Gambar 7 Produk, Website dan Akun social media Sukhacitta (b) Sumber: https://www.sukhacitta.com dan Instagram Sukhacitta

1. Sukkhacitta (Gambar 6 dan 7)

a. Bentuk: Potongan - potongan baju yang sedeharna dan nyaman dipakai

b. Warna natural dari pewarna alam: merah bata, biru indigo, cream, abu - abu, hijau, coklat kemerahan.

c. Material: sutra dan katun

d. Varian produk : baju dan scarf

e. Style produk: kain cenderung polos, bila ada motif tidak banyak dan berukuran besar

f. Logo: pengembangan dari simbol infinitiy, merepresentasikan bahwa sukkha citta adalah brand yang berkelanjutan dengan bertangggung jawab pada lingkungan dan mensejahterakan pembuatnya. 
g. Website: Sukhacitta dengan jelas menyebutkan visinya dalam tagline, setiap pembelian memiliki tujuan \#maderighteconomy.

h. Konten social media: proses pembuatan, proses pengolahan material, cerita tentang pengrajin, pemakaian produk, lelang produk secara online untuk membantu pembangunan kampung pengrajin.

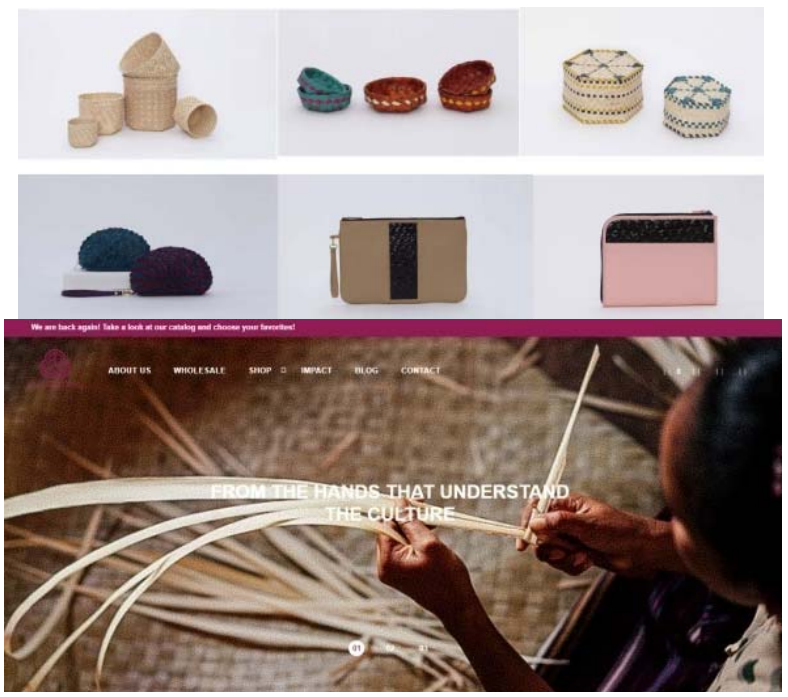

Gambar 8 Produk, Website dan Akun social media Du'Anyam (a) Sumber: https://www.duanyam.com dan Instagram Du'Anyam

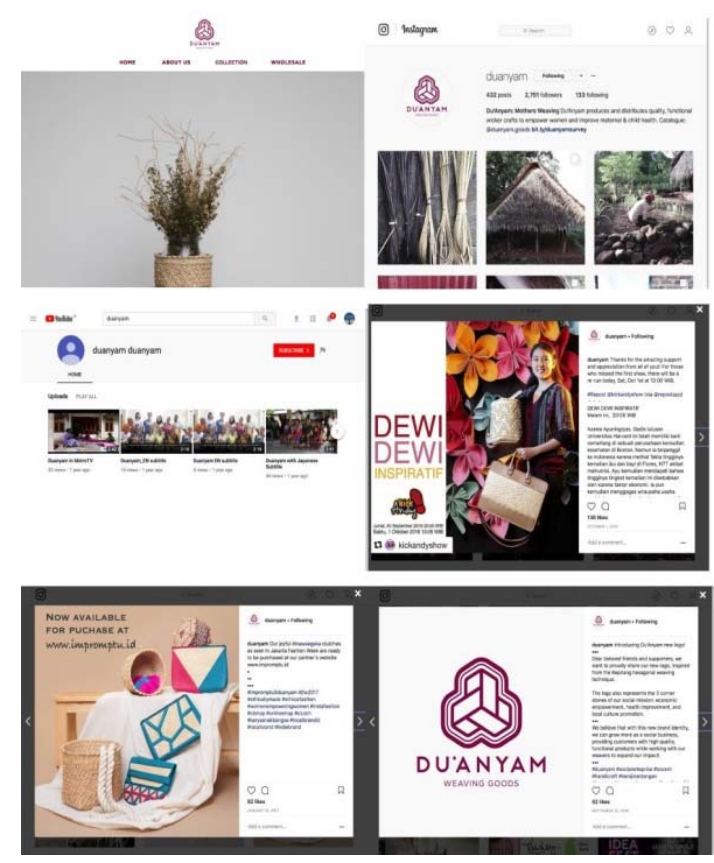

Gambar 9 Produk, Website dan Akun social media Du'Anyam (a) Sumber: https://www.duanyam.com dan Instagram Du'Anyam

2. Du'Anyam (Gambar 8 dan 9)

a. Bentuk: Geometris: kotak, bulat, tabung, dan segienam.

b. Warna: natural anyaman dan pewarna sintentik (biru, pink, kuning, biru, coklat)

c. Material: daun lontar, mix material anyaman daun lontar dengan kulit sintetis dan kain kanvas.

d. Varian produk : aksesories rumah, fesyen, souvenir e. Style produk: gaya anak muda dengan kombinasi material dan warna - warna terang, bermain pola anyaman.

f. Logo: pengembangan dari pola anyam, merepresentasikan tiga landasan misi dari Du'Anyam yaitu pemberdayaan ekonomi, peningkatan kesehatan, dan promosi budaya lokal.

g. Website: Duanyam dengan jelas menampilkan visinya pada homepage.

h. Konten social media: proses pembuatan, proses pengolahan material, cerita tentang pengrajin, pemakaian produk, kegiatan pameran, seminar seminar, open trip (konsumen diajak untuk melihat desa pembuat produk duanyam di NTT)
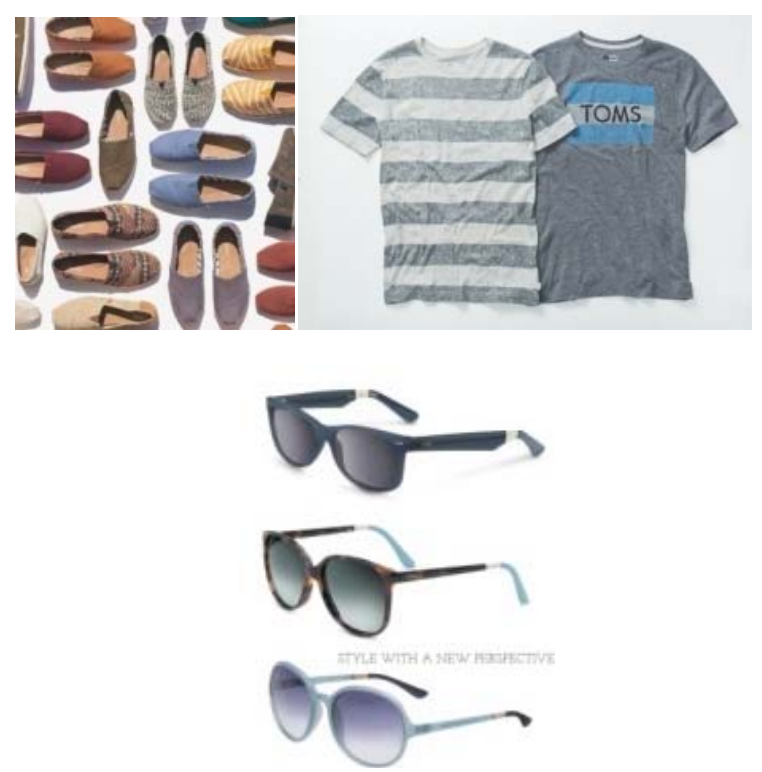

Gambar 10. Produk, Website dan Akun social media Toms (a) Sumber: https://www.toms.com dan Instagram Toms

3. Toms (Gambar 10 dan 11)

a. Bentuk: sepatu alpagartas khas Argentina, tidak keras, flexible mengikuti bentuk kaki, mengutamakan kenyamanan.

b. Warna: casual yang dapat dipakai sehari - hari : hitam, abu-abu, coklat tua, beige biru tua, merah tua.

c. Material: katun, kain kanvas, karet outsole yang fleksibel.

d. Style produk: casual dan nyaman dipakai.

e. Varian produk : sepatu keds, boot, slip on, kaos, dan kacamata.

f. Logo: mengambil bendera Argentina, karena mengingat bahwa visi Toms berawal dari negara ini dan desain sepatu klasiknya diambil dari sepatu tradisional Argentina

g. Konten social media: berbeda dari social enterprise lainnya, toms tidak menampilkan foto-foto pembuat produk Toms, tapi yang ditampilkan adalah foto-foto produk Toms dipakai disegala suasana. Visi social ditampilkan dalam bentuk kutipan kata-kata yang menggugah hati pengamatnya, seperti we are one dan kindness is magic. Diamati Toms tidak secara eksplisit menampilkan foto-foto komunitas yang dibangun Toms. 


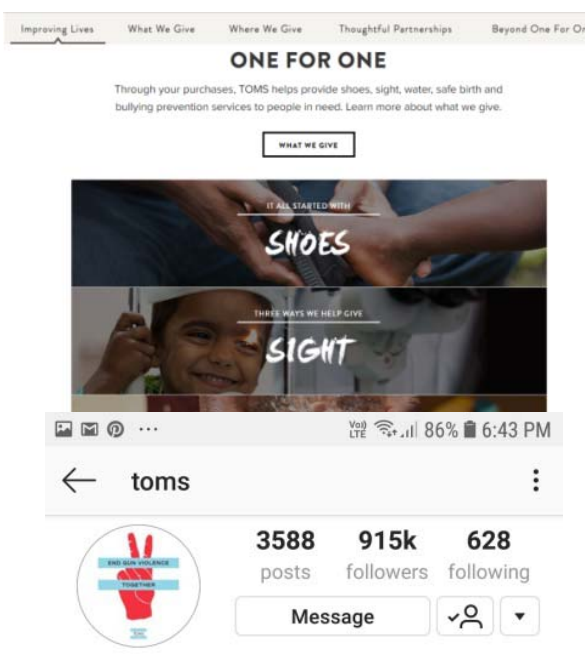

TOMS e

Product/Service

Send a postcard to your representative in less than 30 seconds at TOMS.com to \#endgunviolencetogether

toms.com/
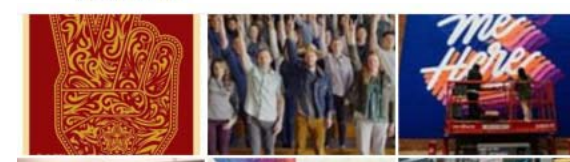

$\therefore$
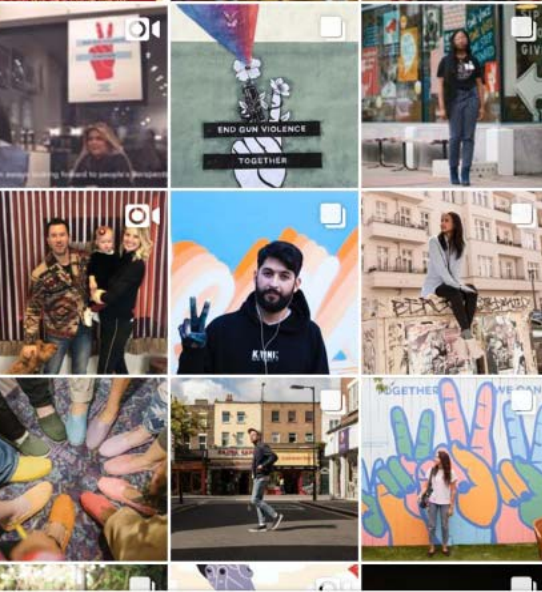

$\widehat{\Omega}$

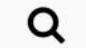

$\oplus$

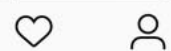

Gambar 11. Produk, Website dan Akun social media Toms (b) Sumber: https://www.toms.com dan Instagram Toms

\section{KESIMPULAN}

Berdasarkan pengamatan, maka nilai design for happiness yang terlihat pada ketiga studi kasus social enterprise ini adalah:

1.Desain untuk memelihara hubungan sosial antara pengusaha dan pekerja, dengan memastikan bahwa mereka dibayar secara adil membuat produk social enterprise. Selain itu, social enterprise juga membangun kehidupan pengrajinnya. TOMS membangun sarana air bersih bagi perumahan pengrajin yang bekerja. Duanyam membuat tabungan kesehatan bagi pengrajinnya,

2. Desain yang memaknai kehidupan seseorang, melalui visinya social enterprise mengajak konsumen bahwa pembeliannya bernilai bukan hanya bagi dirinya sendiri tapi berdampak bagi kehidupan orang lain. Sukhacitta dengan jelas dalam slogannya bahwa setiap pembelian memiliki tujuan.
3. Desain untuk membuat konsumen berpartisipasi aktif, via social media dan kegiatan - kegiatan social enterprise konsumen diajak untuk melihat kontribusi yang sudah diberikan secara online dan offline. Misalnya TOMS memasang foto - foto anak yang disumbangkan sepatu sedang bermain bola di websitenya. Duanyam sering mengadakan open trip bagi konsumen yang ingin melihat proses anyam di rumah anyam duanyam di NTT. Sukkha Citta menggalang lelang produk via social media untuk pembangunan kampung pengrajinnya. Jadi visi social enterprise dapat dirasakan secara riil oleh pekerja dan konsumennya.

Bila dilakukan analisa dalam bentuk matriks relasi nilai dan tampilan yang disajikan bisnis social enterprise (Gambar 12).

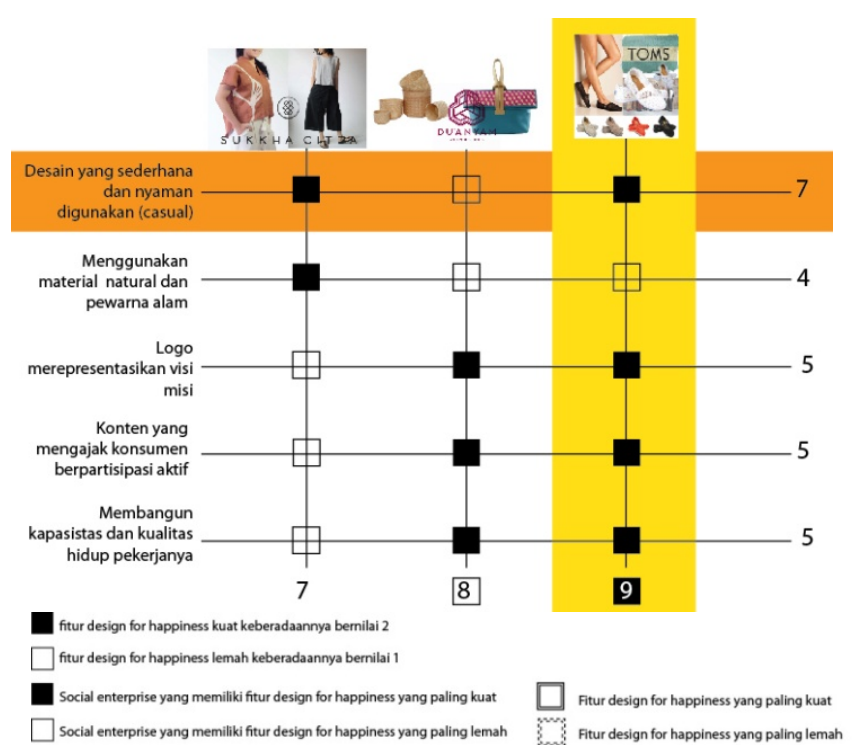

Gambar 12 Matriks relasi nilai dalam bisnis social enterprise

Berdasarkan analisa dengan matriks didapatkan bahwa social enterprise yang memiliki nilai design for happiness yang tertinggi adalah Toms, karena karakter desain yang terlihat pada produk dan konten social medianya sudah mengkomunikasikan visinya sebagai social enterprise, lebih dari itu mengajak konsumen untuk berpartisipasi aktif melalui fitur social media. Dapat disimpulkan karakter desain yang nyaman sebagai hal yang paling bisa dirasakan customer dari visi social enterprise.

\section{UCAPAN TERIMA KASIH}

Penulis ingin mengucapkan terima kasih atas bantuan, bimbingan serta kerjasama dari berbagai pihak yang telah membantu dalam penyusunan karya ilmiah ini. Penulis menyampaikan terima kasih kepadaFakultas Desain Universitas Pelita Harapan DAN LPPM Universitas Pelita Harapan. Artikel ini merupakan bagian dari publikasi penelitian UPH dan terdaftar di LPPM UPH.

\section{DAFTAR PUSTAKA}

[1] Gardien, P., Djajadiningrat, T., Hummels, C., \& Brombacher, A. (2014). Changing your hammer: The implications of paradigmatic innovation for design practice. International Journal of Design, 8(2), 119-13 
[2] Sääksjärvi, M., \& Hellén, K. (2013). How designers and marketers can work together to support consumers' happiness. International Journal of Design, 7(3), 33-44.

[3] Schimmack, U., \& Diener, E. (1997). Affect intensity: Separating intensity and frequency in repeatedly measured affect. Journal of Personality and Social Psychology, 73(6), 1313-1329.

[4] Lyubomirsky, S. (2008). The how of happiness. New York,NY: Penguin Press.
[5] Baumeister, R. F. (1991). Meanings of life. New York, NY: Guilford Press

[6] True Luxury is \#MadeRight. (n.d.). Retrieved from http://www.sukkhacitta.com/

[7] Du'Anyam | Empowering Women through Social Enterprise. (n.d.). Retrieved from http://www.duanyam.com/

[8] TOMS. (n.d.). The One for One ${ }^{\circledR}$ Company. Retrieved from https://www.toms.com/ 